

\title{
Time, Distance and Drawdown Relationships in a Pumped Ground-Water Basin
}

\author{
By Fred Kunkel
}

父 


\section{United States Department of the Interior}

FRED A. SEATON, SECRETARY

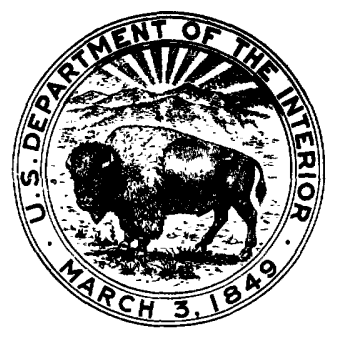

\section{Geological Survey}

THOMAS B. NOLAN, Director

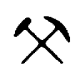

Free on application to the U. S. Geological Survey, Washington 25, D.C. 


\section{CONTENTS}

Page

Page

Abstract.

Computation of drawdown........... 1

Introduction

1

References

\section{8}

ILLUSTRATIONS

Figure 1. Graphs showing relation between drawdown and time at observation points 1,000 and 5,000 feet from pumping well

Page Graphs showing relation between drawdown and time at observation points 500 and 5,000 feet from pumping well.

3. Graphs showing relation between drawdown and time at observation point 5,000 feet from well pumping 4,000 gallons per minute

4. Graphs showing relation between drawdown and distance from pumping well for selected times since pumping began

TABLES

Table 1. Time and quantity of pumpage required to lower the water level 10 feet at observation points 1,000 and 5,000 feet from a pumping well.

2. Time and quantity of pumpage required to lower the water level 10 feet at observation points 500 and 5,000 feet from a pumping well

3. Time and quantity of pumpage required to lower the water level 10 feet at an observation point 5,000 feet from a well pumping 4,000 gpm 


\title{
Time, Distance, and Drawdown Relationships in a Pumped Ground-Water Basin
}

\author{
By Fred Kunkel
}

\begin{abstract}
Several reasonable values are assumed for coefficients of transmissibility and storage of lenticular alluvial deposits. These values when substituted in the Theis (1935) nonequilibrium formula as modified by Wenzel (1942) give curves from which time, distance, drawdown relationships are estimated.
\end{abstract}

\section{INTRODUCTION}

In the development of a ground-water basin one of the principal problems commonly is to determine the effect of pumping on the water level in the basin. Where all the geologic and hydrologic factors are known, it is possible to determine these effects. In many groundwater basins most of the geologic and hydrologic conditions are reasonably well known except the coefficients of transmissibility and storage of the water-yielding deposits. For these basins it is possible to assume reasonable values for the coefficients of transmissibility and storage, and by use of standard formulas estimate probable waterlevel declines caused by pumping. In this paper a range of values is assumed for coefficients of transmissibility and storage that are considered by the author to be reasonable for the Quaternary alluvial deposits of many ground-water basins and are analyzed with reference to water-level declines for various distances and times.

Withdrawal of water from any permeable material causes the water level to decline in the vicinity of the withdrawal, and around a pumping well the shape of the water table or piezometric surface is somewhat like an inverted cone, its apex at the point of withdrawal. This cone is usually called a cone of depression. However, the overall size, shape, and rate of growth of this cone of depression are dependent upon (a) the rate and duration of pumping; (b) the coefficients of transmissibility and storage; (c). the increase in recharge, if any, induced by the declining water levels; (d) the reduction in natural discharge, if any, and (e) boundaries of the ground-water basin. The lowering at any point of the cone of depression is termed drawdown and is dependent upon the above variables and the distance from the pumping.

\section{COMPUTATION OF DRAWDOWNS}

In the following analysis it is assumed that the aquifer is constant in thickness, infinite in areal extent, homogeneous, and isotropic. For these conditions the relationship among the hydraulic properties may be expressed by the nonequilibrium formula developed by Theis (1935)

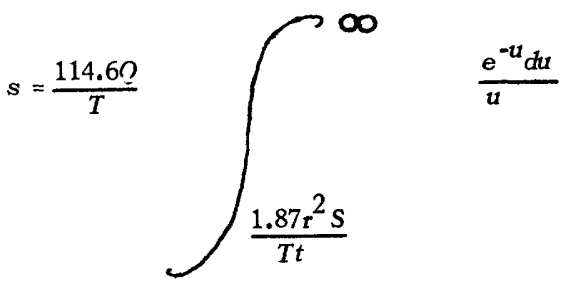

in which $S$ is drawdown, in feet, at any point, in the vicinity of a well pumped at a uniform rate; $Q$ is the discharge of a well in gallons per minute; $T$ is the coefficient of transmissibility of the aquifer in gallons per day per foot; $r$ is the distance of the discharge well from the point of observation, in feet; $S$ is the coefficient of storage, a decimal fraction; and $t$ is the time the well has been pumped in days.

As the coefficient of transmissibility appears on both sides of the equation, the formula cannot be solved directly for $T$ and $S$. However, $T$ and $S$ may be determined by a graphical method described by Wenzel (1942) from the following formulas.

$$
T=\frac{114.6 Q W(u)}{\mathrm{S}}
$$




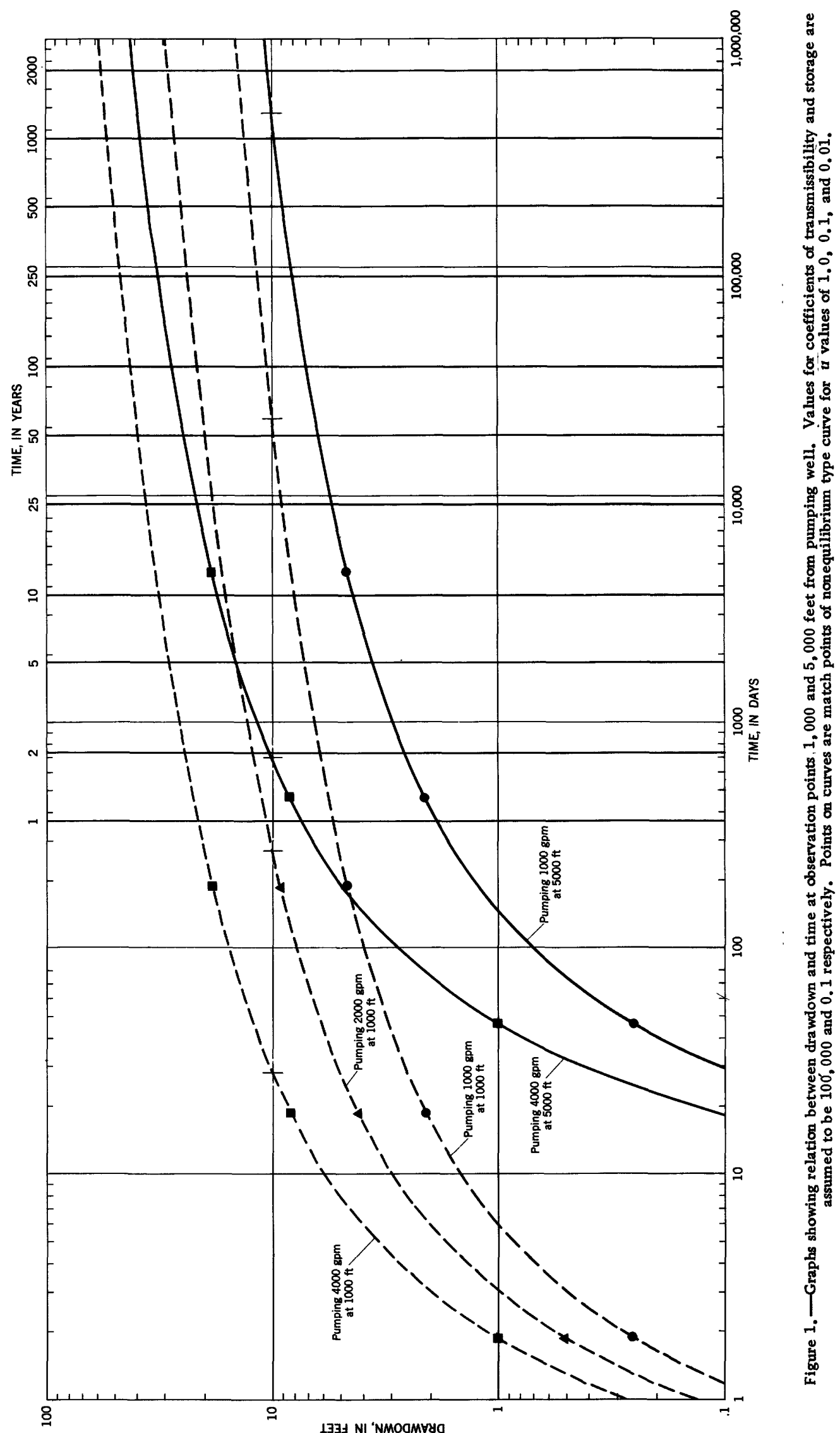


in which $W(u)$ is the "well function of $a$ " and the other terms are as previously defined, and

$$
S=\frac{t T u}{1.87 r^{2}}
$$

Conversely, if the se formulas are modified as follows:

$$
\begin{gathered}
s=\frac{114.6 Q W(u)}{T} \text { and } \\
t=\frac{1.87 r^{2} S}{T u}
\end{gathered}
$$

it is possible to estimate or assume reasonable values for $T$ and $S$ and construct curves that show the time required for any given drawdown at any assumed distance from a pumping well. Accordingly, the accompanying figures graphically show these relationships.

Figure 1 shows two sets of curves for observation points in an aquifer having a coefficient of transmissibility of 100,000 and a coefficient of storage of 0.1 . The first set of three curves are for points 1,000 feet from wells pumping $1,000,2,000$, and $4,000 \mathrm{gpm}$ (gallons per minute). The second set of two curves are for points 5,000 feet from wells pumping 1,000 and $4,000 \mathrm{gpm}$. (See table 1.)

The curves for the observation point 1,000 feet from the pumped well show that it will require about 60 years of pumping at $1,000 \mathrm{gpm}$ to lower the water level 10 feet at the observation point. However, if the pumping rate is increased to $2,000 \mathrm{gpm}$ the 10 feet of drawdown will take about 270 days. If the pumping rate is increased to $4,000 \mathrm{gpm}$ the 10 feet of drawdown will occur in about 28 days. Likewise, at an observation point 5,000 feet from the pumped well it will require about 1,300 years of pumping at $1,000 \mathrm{gpm}$ to lower the water level 10 feet at the observation point. However, if the pumping rate is increased to $4,000 \mathrm{gpm}$ the 10 feet of drawdown will occur in about 700 days or less than 2 years.

Figure 2 shows two sets of curves for observation points in an aquifer having a coefficient of transmissibility of 10,000 and a coefficient of storage of 0.1 . The first set of curves are for points 500 feet from wells pumping 200 and $400 \mathrm{gpm}$. The second set of curves are for points 5,000 feet from wells pumping 400 and $800 \mathrm{gpm}$. (See table 2.)

\begin{tabular}{|c|c|c|c|c|}
\hline \multirow{2}{*}{$\begin{array}{l}\text { Pumping rate } \\
\text { (gpm) }\end{array}$} & \multicolumn{2}{|c|}{$\begin{array}{l}\text { Observation point } 1,000 \text { feet } \\
\text { from pumping well }\end{array}$} & \multicolumn{2}{|c|}{$\begin{array}{l}\text { Observation point } 5,000 \text { feet } \\
\text { from pumping well }\end{array}$} \\
\hline & Time required & $\begin{array}{l}\text { Pumpage required } \\
\text { (acre-feet) }\end{array}$ & Time required & $\begin{array}{l}\text { Pumpage required } \\
\text { (acre-feet) }\end{array}$ \\
\hline $1,000_{\ldots}$ & $\begin{array}{l}22,000 \text { days } \\
(60 \text { years })\end{array}$ & 97,000 & $\begin{array}{l}470,000 \text { days } \\
(1,300 \text { years })\end{array}$ & $2,100,000$ \\
\hline $\begin{array}{l}2,000 \ldots \ldots \\
4,000 \ldots \ldots\end{array}$ & $\begin{array}{l}270 \text { days } \\
(3 / 4 \text { year }) \\
28 \text { days }\end{array}$ & $\begin{array}{r}2,400 \\
500\end{array}$ & $\begin{array}{l}700 \text { days } \\
(1-9 / 10 \text { years })\end{array}$ & 12,000 \\
\hline
\end{tabular}

Table 1.-Time and quantity of pumpage required to lower the water level 10 feet at observation points 1,000 and 5,000 feet from a purmping well

\begin{tabular}{|c|c|c|c|c|}
\hline \multirow{2}{*}{$\begin{array}{l}\text { Pumping rate } \\
\text { (gpm) }\end{array}$} & \multicolumn{2}{|c|}{$\begin{array}{l}\text { Observation point } 500 \text { feet } \\
\text { from pumping well }\end{array}$} & \multicolumn{2}{|c|}{$\begin{array}{l}\text { Observation point } 5,000 \text { feet } \\
\text { from pumping well }\end{array}$} \\
\hline & Time required & $\begin{array}{l}\text { Pumpage required } \\
\text { (acre-feet) }\end{array}$ & Time required & $\begin{array}{l}\text { Pumpage required } \\
\text { (acre-feet) }\end{array}$ \\
\hline $200 \ldots \ldots$ & $\begin{array}{l}610 \text { days } \\
(1-2 / 3 \text { years })\end{array}$ & 540 & (1)- & - - \\
\hline $400 \ldots$ & 70 days & 120 & $\begin{array}{l}7,000 \text { days } \\
(19-1 / 5 \text { years })\end{array}$ & 12,000 \\
\hline $800 \ldots$ & $-\cdots-1---1-n-1$ & 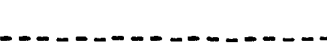 & $1,950 \mathrm{da} \cdot \mathrm{s}$ & 6,900 \\
\hline
\end{tabular}

Table 2.-Time and quantity of pumpage required to lower the water level 10 feet at observation points 500 and 5,000 feet from a pumping well 


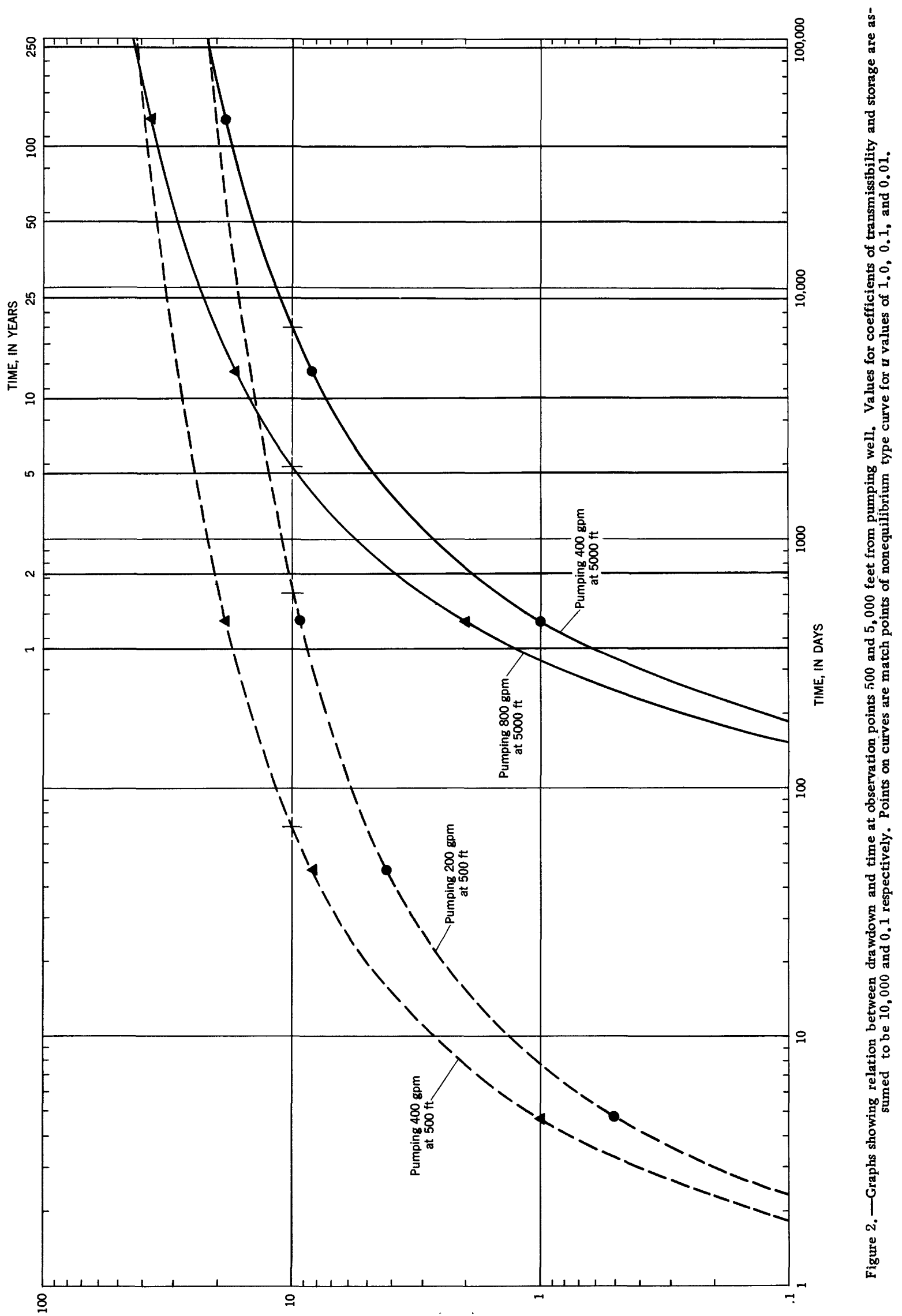




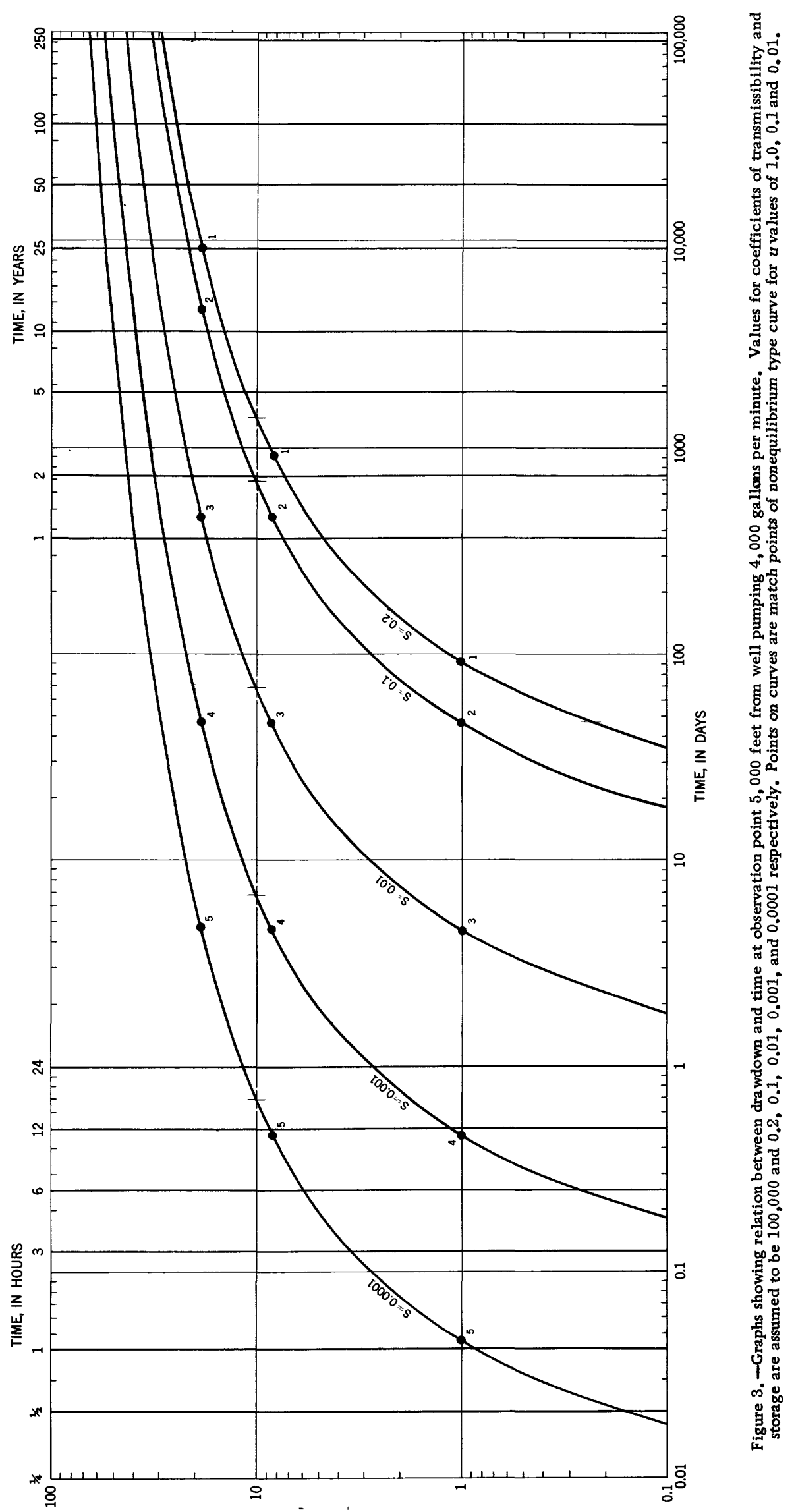


The curves for the observation point 500 feet from the pumped well show that it will require about 610 days of pumping at $200 \mathrm{gpm}$ to lower the water level 10 feet at the observation point. However, if the pumping rate is increased to $400 \mathrm{gpm}$ the 10 feet of drawdown will occur in about 70 days. Likewise, at an observation point 5,000 feet from the pumped well it will require about 7,000 days of pumping at $400 \mathrm{gpm}$ to lower the water level 10 feet at the observation point. However, if the pumping rate is increased to $800 \mathrm{gpm}$ the 10 feet of drawdown will occur in about 1,950 days.

Figure 3 shows a set of five curves for observation points 5,000 feet from wells pumping $4,000 \mathrm{gpm}$ in aquifers having a coefficient of transmissibility of 100,000 and coefficients of storage of $0.2,0.1,0.01,0.001$, and 0.0001 . These curves show that for an $S$ of 0.2 it will require about 1,400 days ( $3-3 / 4$ years) of pumping at $4,000 \mathrm{gpm}$ to cause a drawdown of 10 feet 5,000 feet from the pumping well. For an $S$ of $0.1,0.01,0.001$, and 0.0001 it will require $700,70,7$, and 0.7 days, respectively, for a drawdown of 10 feet to occur at a distance of 5,000 feet. (See table 3.)

In addition to the time required for the 10 feet of drawdown to occur, figures 1-3 show also the total quantity of water, in acre-feet, that would be pumped for the various combinations of conditions. For example, figure 2 shows that if a well, under the conditions assumed, were pumped at $200 \mathrm{gpm}$ for 610 days it would pump approximately 540 acrefeet of water and would cause water-level decline of 10 feet 500 feet from the well. If

Table 3.-Time and quantity of pumpage required to lower the water level 10 feet at an observation point 5,000 feet from a well pumping 4,000 gpm

(Selected values are assumed from the coefficient of storage)

\begin{tabular}{c|c|c}
\hline $\begin{array}{c}\text { Coefficient } \\
\text { of } \\
\text { storage }\end{array}$ & Time required & $\begin{array}{c}\text { Pumpage } \\
\text { required } \\
\text { (acre-feet) }\end{array}$ \\
\hline 0.2 & $\begin{array}{c}1,400 \text { days } \\
(3-3 / 4 \text { years })\end{array}$ & 25,000 \\
\hline 00 days & 12,000 \\
70 days & 1,200 \\
.001 & 120 \\
$.0001-7$ days & 12 \\
\hline
\end{tabular}

the pumping rate were doubled (increased to $400 \mathrm{gpm}$ ) the 10 feet of water-level decline 500 feet from the well would occur in 70 days and only 120 acre-feet of water would be pumped.

Figure 4 shows a set of seven curves after the method of Theis (1938) for selected times in an aquifer having a coefficient of transmissibility of 100,000 and a coefficient of $s$ of 0.1 . Drawdown is plotted against distance from a well pumping $1,000 \mathrm{gpm}$ at the end of $0.1,1$, $10,100,1,000,10,000$, and 40,000 days. These graphs show that, under the conditions assumed, a drawdown of $1 \frac{1}{2}$ feet would occur in 2 hours and 24 minutes at a point 100 feet from the well pumping $1,000 \mathrm{gpm}$. However, it would require about $2-3 / 4$ years of pumping for the same drawdown to occur at 9,000 feet. Similar relationships can be shown for other times.

It justifiably may be questioned if a theoretical analysis as presented herein is applicable to ground-water basins as they occur in nature. For example, figure 1 shows that if a well, under the conditions assumed, were pumped at $1,000 \mathrm{gpm}$ for 1,300 years it would pump about 2,100,000 acre-feet of water and would cause a decline of water level of only 10 feet 5,000 feet from the pumped well. There probably is no ground-water basin in which this would occur even if the coefficients of transmissibility and storage were as assumed. Unless the aquifer or basin were truly of infinite areal extent, the cone of depression would have gone to the boundaries of the aquifer, and resulting image effects would have caused a drawdown much greater than 10 feet in less than 1,300 years. In virtually all aquifers of limited areal extent, boundary ef fects commonly result in drawdowns greater than those calculated for aquifers of infínite extent. Also, the preceding analysis does not allow for either an increase in recharge or a decrease in discharge which eventually must occur in any pumped aquifer.

However, figures 1 and 2 graphically demonstrate that an increase of pumping in an aquifer accelerates the rate of drawdown of the cone of depression at a rate proportionally much greater than the increased rate of pumping. Figure 3 graphically demonstrates that the rate of growth of the cone of depression is inversely proportional to the coefficient of storage. This is an important consideration because artesian aquifers commonly have coefficients of storage of about 0.001 or 


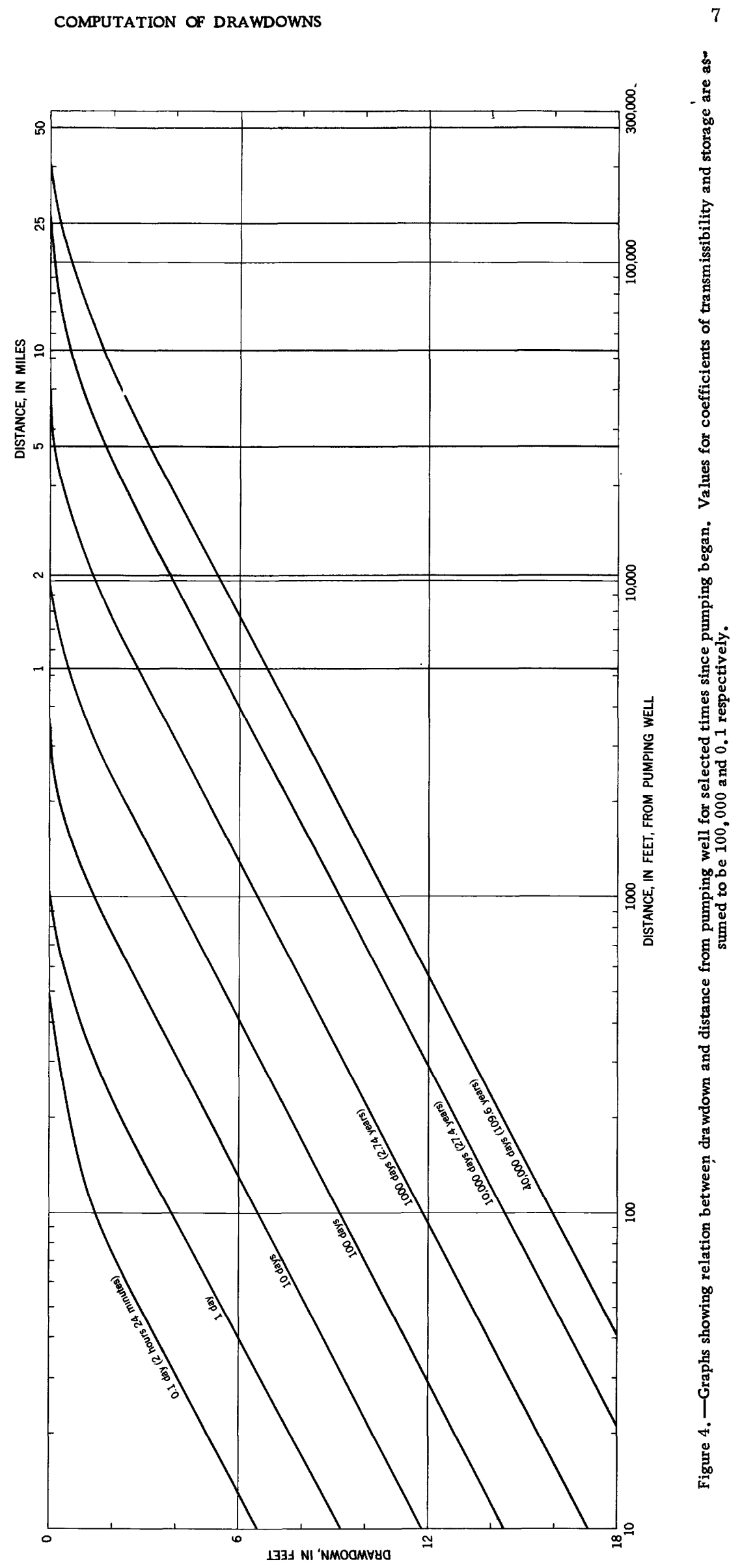


less, whereas nonartesian aquifers commonly have coefficients of storage of 0.1 or more. Hence, the cone of depression in an artesian aquifer grows 50 to 100 times as fast as it does in nonartesian aquifers.

Figure 4 demonstrates that within a few tens of years even for relatively low rates of pumping significant water-level declines occur at distances of several miles from the pumping. If these rates are increased as shown by figure 1 the water-level decline occurs at a greatly accelerated rate.

In summing up this discussion the following points, in large part after Theis (1938 and 1940), should be emphasized.

1. All water discharged by wells is balanced by a loss of water somewhere.

2. This loss is always to some extent, and in many cases largely, from ground water in storage in the aquifer.

3. However, after sufficient time has elapsed for the cone of depression to reach the area of recharge, further discharge by wells will be made up in part by an increase in the recharge if previously there has been rejected recharge.

4. Again, after sufficient time has elapsed for the cone of depression to reach the areas of natural discharge, further discharge by wells will be made up in part by a diminution in the natural discharge.

5. In artesian aquifers, compared to nonartesian aquifers, relatively little water is taken from storage. In artesian aquifers, because the cones of depression spread with great rapidity, each well in a short time has its maximum effect on the whole aquifer and obtains most of its water by an increase of recharge or decrease of natural discharge. In large nonartesian aquifers, where pumping is done at great distances from the localities of intake or outlet, however, the effects of each well are for a considerable time confined to a rather small radius and the water is taken from storage in the vicinity of the well.

6. In localities developing water from nonartesian aquifers and remote from areas of rejected recharge or natural discharge, the conditions connoted by the concept of perennial yield ${ }^{1}$ may not be reached for several centuries and virtually all the water used may be taken from storage. If pumping in such a locality is at a rate that will result during the course of 10 years in a lowering of water level to a depth from which it is not feasible to pump, pumping at half this rate would not cause this lowering in 100 years. However, the converse also is true. If past pumping in an aquifer of limited extent has caused only a moderate decline of water levels during the period of pumping, doubling the rate of pumping will in the future cause a decline of water level many times greater than past pumping.

7. Finally, even if a well discharges only a short time and draws its water for the time entirely from ground water in storage in the aquifer, eventually the aquifer must either discharge just that much less water through natural outlets or take in that much more water in the intake area. Hence, the cone of depression can have no ultimate limits short of at least one of the hydrologic boundaries of the aquifer.

\section{REFERENCES}

Theis, C. V., 1935, The relation between the lowering of the piezometric surface and the rate and duration of discharge of a well using ground-water storage: Am. Geophys. Union Trans., p. 519-524.

-1938, The significance and nature of the cone of depression in ground-water bodies: Econ. Geology, v. 33, no. 8, p. 889-902. 1940, The source of water derived from wells: Am. Soc. Civil Engineérs, Civil Eng., p. 277-280.

Wenzel, L. K., 1942, Methods for determining permeability of water-bearing materials: U.S. Geol. Survey Water-Supply Paper 887.

\footnotetext{
1Perennial yield of a ground-water basin may be defined as the rate at which ground water can be withdra wn year after year without depleting the ground-water storage to such an extent that withdrawal at this rate is no longer feasible because of increased pumping costs or deterioration of water quality.
} 